\title{
Consumer credit regulation after the fall: international dimensions
}

\author{
Iain Ramsay
}

(C) Springer-Verlag 2012

Zusammenfassung: Wie die jüngsten Entwicklungen, etwa die Bemühungen zum Erstellen von „Good Practices“ durch die Weltbank oder der Entwurf der OECD zum Verbraucherschutz bei Finanzierungsgeschäften, zeigen, gehört die Regulierung des Verbraucherkreditsektors mittlerweile (in bescheidenem Umfang) zur internationalen Wirtschaftsregulierung. Der folgende Beitrag geht der Frage nach, ob es überhaupt ein gemeinsames internationales Verständnis für das Institut des Verbraucherkredits in der Wirtschaft gibt. Untersucht werden verschiedene Zugänge, etwa das Lebenszyklusmodell, ein Phänomen, das den Verbraucherkredit als Einkommensersatz sieht, sowie die Verhaltensökonomik. Ausgehend von der herrschenden Uneinigkeit über die optimale Rolle des Verbraucherkredits spricht sich der Beitrag für einen effektiven politischen Dialog bei der Regulierung von Verbraucherkrediten aus und beleuchtet die regulative Entwicklung auch aus volkswirtschaftlicher Sicht. Dem Vorschlag der Bildung einer internationalen Informationsagentur, die die Maßstäbe für Verbraucherkreditregulierung setzen und diese auch begleiten und überwachen soll, könnte - entsprechenden Input von Verbraucherseite vorausgesetzt - eine nützliche Innovation darstellen. Der Beitrag beschäftigt sich auch kurz mit den neuen Regulierungsbehörden, die sich nach der Finanzkrise entwickelt haben und streicht hervor, warum es unerlässlich ist, auch Vorschriften für Überschuldung und Verbraucherinsolvenz als Teile der Grundstruktur für die Regulierung des Verbraucherkreditmarkts zu sehen.

Professor Iain Ramsay $(\bowtie)$

Kent Law School, University of Kent, CT2 7NS Canterbury, UK

e-mail: <i.d.c.ramsay@kent.ac.uk>

\section{Introduction}

Regulation of consumer finance is now a modest aspect of international economic regulation. International principles and best practices for consumer finance regulation are emerging in the wake of a world financial crisis ${ }^{1}$ triggered by problems of US housing debt. These principles and practices embrace the role of disclosures, control of unfair and abusive business practices, redress mechanisms, product regulation and the establishment of new institutions of regulation ${ }^{2}$. The OECD's Draft High Level Principles on Financial Consumer Protection indicate that 'financial consumer protection should be an integral part of the legal and regulatory framework' and that 'financial consumers should be treated equitably, honestly and fairly at all stages of their relationship with financial providers' ${ }^{3}$. Consumers International (CI) proposes an international organization 'with the ability to conduct research and publish national peer reviews' based on the OECD principles. It 'should have an independent consumer panel to monitor, advise and challenge the work of the organisation' ${ }^{\text {'4 }}$. This organization would "ensure that the consumer perspective was represen-

\footnotetext{
${ }^{1}$ See for example Financial Stability Board, Progress in the Implementation of the G20 Recommendations for Strengthening Financial Stability (2011) 10; OECD, Draft High Level Principles on Financial Consumer Protection (August 2011); World Bank, Good Practices for Consumer Financial Protection: Consultative Draft (2011).

${ }^{2}$ Ramsay/Williams, The Crash that launched a thousand fixes: regulation of consumer credit after the lending revolution and the credit crunch, in Alexander/Moloney, Law Reform and Financial Markets (2011) 219; World Bank, Good Practices for Consumer Financial Protection: Consultative Draft 97.

${ }^{3}$ OECD, Draft High Level Principles on Financial Consumer Protection 5 .

${ }^{4}$ Consumers International, Comments on the OECD Draft High Level Principles on Financial Consumer Protection (public consul-
} 
ted in international debates'. At a regional level the restructuring of the European financial architecture now includes specific responsibilities for consumer protection ${ }^{5}$.

These international documents assume that consumer credit is an international phenomenon, that failures of national consumer finance protection can have systemic and international consequences, and that there are a common set of issues, assumptions and good practices, albeit tailored to different levels of development. The development of a world 'common sense' about consumer credit and its regulation, signals the growth of consumer finance as a distinct field of international, regional and national regulation. One wonders however about the sources of influence on its development in short the political economy of this internationalization of consumer finance regulation. The World Bank Good Practices "seek to state measures that evoke general agreement among regulators": an impressionistic take on the sources for the World Bank Good Practices highlights the influence of EU, UK and US regulations and practices - in that order. International regulation often privileges expertise and informal networks ${ }^{7}$, raising questions about its legitimacy and accountability. Existing studies of international standard setting underline the difficulties facing consumer influence at the regional and international level ${ }^{8}$ and ALTER-EU has highlighted the dominance of financial interests in the expert committees of the $\mathrm{EU}^{9}$. The World financial crisis underlines the challenge of achieving an effective political dialogue on issues such as consumer credit.

This article poses some initial questions concerning a global commonsense about consumer credit and its regulation. First, is there international agreement as to the optimal role of consumer credit in the economy? Household credit during the past thirty years has been a significant source of bank profits ${ }^{10}$. However, substantial differences exist even between developed economies within the EU in levels of consumer and housing credit, in the balance of co-operative and for profit financial institutions, in attitudes to cre-

tation August 2011) $3<$ consumersinternational.org/media/787929/cicomments-on-oecd-draft-on-financial-consumer-protection-full.pdf>.

${ }^{5}$ See Art 9 European Supervisory Authority Regulation 1093/2010/EU.

${ }^{6}$ World Bank, Good Practices for Consumer Financial Protection: Consultative Draft (2011) $100<$ siteresources.worldbank.org/ EXTFINANCIALSECTOR/Resources/Good_Practices_Financial_ CP.pdf $>$.

${ }^{7}$ Morgan/Yeung, An Introduction to Law and Regulation (2007) 310311, 333-334.

${ }^{8}$ See generally Consumers International, Decision Making in the Global Market: Trade Standards and the Consumer (2005).

${ }^{9}$ ALTER-EU, A captive Commission - The role of the financial industry in shaping EU regulation Brussels (2009) 3-23 < greenpeace. org/eu-unit/Global/eu-unit/reports-briefings/2009/11/a-captivecommission-5-11-09.pdf>.

${ }^{10}$ Dos Santos, On the Content of Banking in Contemporary Capitalism, Historical Materialism 2009, 180 (190-193). dit, approaches to regulation, and forms of regulation ${ }^{11}$. Do these differences suggest an over-development in some economies or an under-development in others? In 2006 a French report suggested that the French were 'under-indebted' in comparison with their Anglo-Saxon neighbours, and that it was desirable to alter the law to facilitate more $\mathrm{credit}^{12}$. In contrast more recent French reports claim that the relatively tight usury limits on mortgages was one factor in preventing the development of a large sub-prime mortgage market ${ }^{13}$. Different assumptions about consumer credit have consequences for regulation, and for inclusion and exclusion of consumers within the credit market. The EU Mortgage Lending Directive assumes that responsible lending will have the desirable consequence of excluding certain consumers from the risks of over-indebtedness ${ }^{14}$.

Second, a characteristic of the responses to the crisis has been the reinvigoration of public regulation with the model of a dedicated expert consumer finance regulator operating at the national level, possibly linked with other national and regional regulators. This new regulation is associated with more ex ante control on suppliers and forms of consumer credit, for example through greater 'collective hands tying' by suppliers, the possibility of swift action to address toxic products, and a focus on 'product governance' to ensure that 'new products truly do serve the needs of the customers to whom they are marketed ${ }^{15}$. This regulation may also be justified in distributional terms as more effective in protecting vulnerable groups. This approach assumes that competition and regulation of the sales process have not provided sufficient protection. A primary objective here is to prevent systemic problems such as the problems with payment protection insurance in the UK, another subprime mortgage debacle, or the political debacle associated with microcredit in India ${ }^{16}$. A further objective of ex ante regulation is to re-constitute or embed markets within norms of trust and cooperation between lender and borrower.

\footnotetext{
${ }^{11}$ On attitudes to credit see Eurobarometer 60.2 where significantly higher percentages of UK, and Swedish consumers consider credit to be useful than French or German consumers <ec.europa.eu/public opinion/archives/ebs/ebs_202_report.pdf>.

${ }^{12}$ Bourdin, Accès des ménages au credit en France. Délégation du Sénat sur la Planification (2006) 7. See also Maussion, Faut-il s'endetter plus?, Libération 13.06.2007, 13.

${ }^{13}$ Lefebvre, Rapport d'Information No 744 sur les emprunts immobiliers à taux variable, Assemblée Nationale (2008) 55-56 $<$ assembleenationale.fr/13/rap-info/i0744.asp >.

${ }^{14}$ European Commission, Proposal for a Directive on credit agreements relating to residential property, COM (2011) 142 final.

${ }^{15}$ Financial Services Authority, Discussion Paper 11/1, Product Intervention (2011) $3<$ fsa.gov.uk/pubs/discussion/dp11_01.pdf > .

${ }^{16}$ Bajaj, Luster Dims for a Public MicroLender, New York Times 11.05.2011 <query.nytimes.com/gst/fullpage.html?res= 9F03E4DF113AF932A25756C0A9679D8B63\&ref=microfinance>.
} 
Part 2 introduces economic ideas which influence consumer credit policy. It outlines the dominant economic 'commonsense', the lifecycle model of credit use, and alternative approaches based on a 'loan for wages' model and behavioural economics, noting also the patterning effects of economic ground rules. It discusses the implications of these alternatives for policymaking. The article argues that the uncertainty among experts as to the optimal role of credit and forms of regulation underlines the importance of effective political dialogue on the enactment and implementation of regulation. This theme is pursued in the context of the recent internationalization of regulation and the role of expert networks. Part 3 turns to issues of institutional architecture and discusses the role of expert regulation and the greater interest in ex ante regulation of credit markets, to prevent systematic failures. Part 4 discusses consumer insolvency as part the new international financial architecture. Part 5 concludes.

\section{Assumptions about the role of consumer credit in the economy}

Consumer credit and the lifecycle model of consumption

An influential approach in economics argues that consumer credit plays an important role in lifecycle budgeting, balancing saving and spending and income smoothing ${ }^{17}$. Households may commit future income to present consumption needs based on their lifetime income expectations. If income in the future is expected to increase then it is optimal to borrow to finance present consumption. Conventional analysis indicates that "lending and borrowing make it possible to redistribute spending from periods in the lifecycle in which income is high to periods in which it is low"18. Since earnings are generally 'hump shaped', younger consumers may be expected to borrow more. Consumer credit permits the accumulation of capital assets such as homes but also depreciating assets (washing machines, etc) which provide immediate services which might substitute for more expensive external services (such as a commercial laundry). Borrowers might however be constrained in access to credit particularly when they are younger. The deregulation of the $1980 \mathrm{~s}$ permitted consumers to achieve a more desirable balance of consumption and saving. Instalment repayments provide also the discipline of forced saving, countering the argument that increased credit undermined a savings culture. Consumers may underuse credit because of uncertainty as to the future so that one role of regulation is to stimulate trust and confidence in credit markets. A well functioning consumer credit

\footnotetext{
${ }^{17}$ Bertola/Disney ea, The Economics of Consumer Credit 6 (2006).

${ }^{18}$ Bertola/Disney ea, The Economics of Consumer Credit 6.
}

market could therefore enhance consumers' capabilities - to use Sen's phrase ${ }^{19}$. Even the poor may benefit from credit through the use of consumer credit for income smoothing.

The arguments summarized above were made by the Crowther Committee (1971) in the UK, chaired by Geoffrey Crowther, the mercurial economist and ex-editor of The Economist when consumer credit was in its infancy in the UK. These arguments were important legitimators for the development of consumer credit to an increasingly banked population. The EU repeated them in an early draft of the Consumer Credit Directive stating that 'credit is the lubricant of economic life ${ }^{20}$ and they influenced attempts by countries such as France and Italy to increase the role of consumer credit in the economy. A Bank of England report argued in 2004 that a relatively high level of debt may signal an improvement in welfare because 'consumers have had the opportunity to smooth through short-term falls in income, or to raise consumption to match expectations of higher or more certain income ${ }^{21}$. Similar arguments are made in relation to credit for developing countries, that consumer credit permits income smoothing and that it may be beneficial to poorer consumers. The lifecycle model of consumer behaviour remains influential in policy making and financial literacy strategies, and in explaining patterns of indebtedness at different stages of the lifecycle. Critics do point to anomalies in savings behavior between countries, cross cultural differences, and evidence of increased debt, over-indebtedness and bankruptcy among older consumers ${ }^{22}$ which pose questions about the model ${ }^{23}$. The increased availability of credit without fixed repayment schedules - the credit card being the classic example - also loosens the discipline of the traditional instalment plan.

The economics of information supplies a second pillar of international conventional wisdom in regulation drawing attention to failures on the supply and demand side of the market. Information failures might cause credit markets to fail to clear, i.e. there will be unmet demand because of information problems of adverse selection and moral hazard ${ }^{24}$.

\footnotetext{
${ }^{19}$ See generally Sen, Development as Freedom (1999) and subsequent discussion in Sen, The Idea of Justice (2009) 18-19, 231 et seqq.

${ }^{20}$ See Proposal for a Directive of the European Parliament and of the Council on the Harmonisation of the laws regulation and administrative provisions of the Member states concerning credit for consumers COM (2002) 443 final.

${ }^{21}$ Hancock/Wood, Household Secured Debt, Bank of England Quarterly Bulletin 2004, 291 <bankofengland.co.uk/publications/quarterlybulletin/qb040302.pdf>.

${ }^{22}$ Mann/Mann, Debt, Financial Distress, and Bankruptcy over the Life Course (2011) 8, 10-11 <works.bepress.com/ronald_mann/32/>.

${ }^{23}$ Browning/Crossley, The Lifecyle Model of Consumption and Saving, Institute of Fiscal Studies WP01/15 (2001) <ifs.org.uk/wps/ wp0115.pdf>

${ }^{24}$ The classic exposition is Stiglitz/Weiss, Credit Rationing in Markets with Imperfect Information, American Economic Review 71 (1981) 393-410.
} 
This literature drove international and regional proposals for greater information sharing through credit bureaux and other mechanisms which might substitute for information, for example facilitating access to security and collateral. The World Bank argues that 'credit reporting... is a crucial component of modern financial systems and a critical driver for efficiency in lending to consumers ${ }^{25}$. The existence of reporting would increase access and reduce default, a social cost of the system. As a general proposition this may be true but the role of different types and forms of credit bureaux remains a complex public policy issue both in terms of its effect on financial inclusion, forms of marketing, and its interaction with privacy rights ${ }^{26}$.

Consumer credit: loans for wages?

Barba/Pivettti challenge the lifecycle model as a description of the growth in household debt in the US and UK economies since the 1980s. They argue that the role of credit in these economies should rather be characterised as "loans for wages" ${ }^{27}$. Consumer debt compensated for relatively stagnant disposable incomes and reductions in the welfare state as globalization, with the abolition in barriers to the mobility of capital, permitted capital to be increasingly free of labour power. Consumer debt was an 'effort by low and middle income households to maintain as long as possible their relative standards of consumption in the face of persistent changes in income distribution in favour of households with higher incomes ${ }^{28}$. Within this model, the male breadwinner model of the family was replaced by a model where families rely on two incomes for survival, creating increased dangers of downward mobility in the event of sickness, accident or unemployment occurring to one income earner ${ }^{29}$.

The growth in inequality during the period since 1979 was masked therefore by the ability of individuals to use credit to purchase a 'taste' if not an equal share of the economic pie $^{30}$. However, credit was often offered on terms which reflected regressive cross-subsidisation between consumers, further increasing inequalities. Given these facts it is not surprising that the rise in formal measures of over-indebtedness

\footnotetext{
${ }^{25}$ World Bank, Good Practices for Consumer Financial Protection: Consultative Draft 89.

${ }^{26}$ Ferretti, The Law and Consumer Credit Information in the European Community: The Regulation of Credit Information Systems (2008).

${ }^{27}$ Barba/Pivetti, Rising household debt: Its causes and macroeconomic implications - a long-period analysis, Cambridge Journal of Economics 2009, 113, 121.

${ }^{28}$ Barba/Pivetti, Cambridge Journal of Economics 2009, 113, 121122.

${ }^{29}$ See Warren/Warren Tyagi, The Two-Income Trap: Why Middle Class Mothers and Fathers Are Broke (2003) especially ch 3.

${ }^{30}$ Manning, Credit Card Nation: The Consequences of America's Addiction to Credit (2000) 124.
}

in countries such as the UK and US has been concentrated in lower middle-class and lower-income populations which have the highest ratio of debt to income and assets as well as the highest debt-service ratio. A characteristic of those countries with this model of economy has been relatively "high" levels of bankruptcy and insolvency.

The loans for wages model may not fit easily all European countries. Its implications are a higher level of default on debts, which may vary from one or two missed payments to bankruptcy, with a continuing need to reintegrate individuals within the credit system. This was achieved in the US by a generous consumer bankruptcy system and European countries have since the 1980s made debt adjustment and personal insolvency more accessible ${ }^{31}$. There is evidence in the wake of the crisis of an attempt to return to the loans for wages model in the US and UK with the associated idea that empowered consumers drive productivity. There is not a great deal of evidence supporting this latter assumption. France, with a model of consumer protection and a substantially lower level of consumer and mortgage credit, has a higher level of productivity than the UK.

Several responses to the loans for wages model are possible. First, given the importance of loans it is imperative that consumers be well informed and "responsibilized" about the risks associated with loans. This approach has spawned the financial literacy movement. Second, just as an individual might seek a secure wage then policy should encourage secure loans through measures such as responsible lending. However this may dampen the supply of credit which in turn undermines the growth aspect of credit. Third, loans for wages suggests that some individuals will continue to need credit for everyday survival in a recession, underpinning the importance of financial inclusion. Given the public role of credit as wages treating it as a form of public utility or 'service of general interest' becomes more compelling. Finally, given its potential unsustainability there is the question of the future of the loans for wages model in an age of austerity and reduced credit availability.

\section{Consumer credit and the behavioural revolution}

Consumer credit regulation must now be assessed in the light of behavioural economics which argues that individuals may not act rationally in relation to saving and spending. Consumers may favour the short term over the long term, underestimate risk and be over-confident in their ability to stay out of trouble. Individuals may also act in a herd like fashion. The literature on behavioural economics and credit

\footnotetext{
${ }^{31}$ Ramsay, Between Neo-Liberalism and the Social Market: Approaches to Debt Adjustment and Insolvency in the EU, in EUI Law Working Paper 2011/09, 5 <cadmus.eui.eu/bitstream/handle/1814/18255/2011_ 09 .pdf? sequence $=1>$.
} 
is now large $\mathrm{e}^{32}$ and influences policy making internationally. Examples include the Office of Fair Trading, the OECD and DG Sanco, which has recommended that it be taken into account in interpreting the Unfair Commercial Practices Directive ${ }^{33}$. Behavioural analysis provides support for a conception of credit as a potentially dangerous product, a conception with a long history, and most recently highlighted by Warren $^{34}$.

Neo-classical models assume the virtues of competition and disclosure in credit markets but behavioural analysis indicates that competition in credit markets may be systematically skewed to taking advantage of the behavioural biases of consumers ${ }^{35}$. Firms that do not adopt this strategy may not prosper. Competition does not necessarily result in new entrants offering choices which might be more welfare enhancing. Adair Turner, chair of the Financial Services Authority, recently mused that "it is notable that some of our greatest concerns about high distribution margins and inappropriate advice have arisen in activities... characterised by huge numbers of competitive firms ${ }^{\prime \prime 36}$, and the FSA concludes that "it is inherently more difficult for competition in retail financial services to be as effective as it is in other consumer services" ${ }^{\prime 3}$. This is partly because in the case of credit, consumers are primarily interested in price and there is less opportunity for quality differentiation as is possible with products. True transparency in credit pricing reduces substantially the profitability of companies so that profits must come from obscuring additional costs such as insurance, etc.

The insights of behavioural economics have been used to question the efficacy of existing information strategies and resulted in many innovations such as the use of 'key facts' in disclosures. Behavioural insights have inspired a variety of

\footnotetext{
$\overline{32}$ For a summary of studies until 2007 see Ramsay, Consumer Law and Policy: Text and Materials on Regulating Consumer Markets (2007) 71 et seq; see also the special issue of the Journal of Consumer Policy 'Behavioural Economics, Consumer Policy and Consumer Law' 3/2011; Duggan/Ramsay, Front End Approaches to Access to Justice: The Example of Consumer Credit, in Trebilcock/Duggan/Sossin, Improving Access to Justice for the Middle Class (forthcoming).

${ }^{33}$ See Commission Staff Working Document: Guidance on the Implementation/Application of Directive 2005/29/EC on Unfair Commercial Practices <ec.europa.eu/consumers/rights/docs/ Guidance_UCP_Directive_en.pdf $>$.

34 Warren, Unsafe at any rate, Democracy 2007, 8, 11-18.

${ }^{35}$ Mann, Bankruptcy Reform and the "Sweat Box" of Credit Card Debt, Illinois Law Review 2007, 375; Bar-Gill, The behavioral economics of consumer contracts, Minnesota Law Review 2008, 749 761-772, 776-780; Bar-Gill/Warren, Making Credit Safer, University of Pennsylvania Law Review 2008, 1.

${ }^{36}$ Turner, Reforming Finance: Are we being radical enough? (2011) 24 $<$ fsa.gov.uk/pubs/speeches/0218_at_clare_college.pdf $>$

${ }^{37}$ Financial Services Authority, Product Intervention 5 (cf fn 15).
}

'nudging' strategies to enhance consumer decision making ${ }^{38}$. There may be limits to nudging however ${ }^{39}$ in addressing problems such as over-indebtedness so that greater supply side and ex ante regulation may be necessary. Controversies concerning the application of behavioural insights to consumer policy often turn on ideological arguments about autonomy versus paternalism, the extent to which limiting some individuals' choices may benefit others. Thaler/Sunstein, for example have an ideological preference for consumer choice, and generally oppose product bans, favouring the restructuring of 'choice architectures'.

Institutional patterning and consumer credit markets

The behavioural literature raises questions about what counts as an autonomous choice. But this individualistic focus obscures the collective issues raised by behavioural analysis of financial crises, namely the "herd" nature of both the supply and demand side of the market - described in the 1930s by Keynes as 'animal spirits' 40 - captured more recently by the concept of 'irrational exuberance' ${ }^{41}$. It draws attention to the 'social habit structure' of credit markets ${ }^{42}$. This 'habit-structure' is partly constituted by the institutional structure of regulation - the ground rules of the market. This institutional approach stresses the long term patterning effects of market ground rules ${ }^{43}$. John Kenneth Galbraith originally described this effect when he outlined the twin roles of permitting extensive advertising and consumer credit in 'want creation' in the US during the post secondworld-war era and in creating a culture of private consumption - a Consumers' Republic - promising increased welfare and equality through private consumption ${ }^{44}$. Galbraith's thesis of 'want creation' became unfashionable among neoclassical economists partly because it was difficult to model but it now has some empirical support ${ }^{45}$ and Offer links advertising and credit in his dissection of the contemporary

\footnotetext{
${ }^{38}$ Thaler/Sunstein, Nudge: Improving Decisions About Health, Wealth and Happiness (2008) 4-14 (describing 'libertarian paternalism').

${ }^{39}$ House of Lords Science and Technology Select Committee 2nd Report of Session 2010-12, Behaviour Change, HL Paper 179 (2011) 5, 35-36 <publications.parliament.uk/pa/ld201012/ldselect/ ldsctech/179/179.pdf>.

${ }^{40}$ Keynes, The General Theory of Employment, Interest and Money (1936) 161-162.

${ }^{41}$ See generally Shiller, Irrational Exuberance (2005).

${ }^{42}$ Brown, Inequality Consumer Credit and the Savings Puzzle (2008).

${ }^{43}$ Ramsay, Consumer Law Distributive Justice and the Welfare State, Oxford Journal of Legal Studies 1995, 15; Braucher, Theories of Over-Indebtedness: Interaction of Structure and Culture, 7 Theoretical Inquiries in Law 2006, 323.

${ }^{44}$ See Cohen, A Consumers' Republic (2003) esp ch 3.

${ }^{45}$ Lamdin, Galbraith on Advertising, Credit, and Consumption: A Retrospective and Empirical Investigation with Policy Implications, Review of Political Economy 2008, 595.
} 
challenges of affluence ${ }^{46}$. Offer argues that the ground rules of consumer markets in the US and UK which permit high levels of advertising, and relatively unrestricted access to credit, contributed, along with the stagnation in wages and politically driven ideological change from producerism to consumerism, to an increase in collective 'bads' such as over-indebtedness and obesity.

\section{Implications of theoretical uncertainty}

What flows from these initial reflections on the role of consumer credit in the economy? First, uncertainty exists among 'experts' as to the role of consumer credit in the economy. Second, levels of consumer credit are partly determined by the institutional structure of the market which reflects political choices and history, which may over time be viewed as 'culture'. There is not a 'natural' level of consumer credit. While there may be shared international values on issues such as consumer fraud, consensus may be harder to attain on ground rules which affect the overall level of demand for credit, such as controls on the extent and nature of advertising and marketing or interest rate ceilings. Neoliberal countries, such as the US and UK, elevated consumer choice and access to the credit market over consumer protection from the market and measures which might dampen demand. Whitman argues that this is one difference between the US and France and Germany, where consumer protection from the market may be influential ${ }^{47}$. The Crowther report in the UK, which legitimated the growth of the UK credit market stated this neo-liberal ideology clearly in 1971:

"[T]he state should interfere as little as possible with the consumer's freedom to use his knowledge of the consumer credit market to the best of his ability and according to his judgment of what constitutes his best interests". (...) The first principle of social policy should be "to treat the users of consumer credit as adults who are capable of managing their own financial affairs, and not to restrict their freedom of access to credit in order to protect the relatively small minority who get into difficulties" [para 1.3.5.]

Given competing views on credit, policy makers need to realize that these different views on credit all have some 'truth'. Properly crafted disclosures, taking into account psychological findings ${ }^{48}$ can be useful, but may not be

\footnotetext{
${ }^{46}$ Offer, The Challenge of Affluence: Self-Control and Well-Being in the US and Britain since 1950 (2006).

${ }^{47}$ Whitman, Consumerism versus Producerism: An Essay in Comparative Law, Yale Law Journal 2008, 340.

${ }^{48}$ See e.g. the findings on the impact of different framings of advertisements for credit in Bertrand/Karlan ea, What's Advertising Content Worth? Evidence from a Consumer Credit Marketing Field Experiment, Quarterly Journal of Economics 2010, 263.
}

sufficient. Regulation of 'advertising style' - such as those stressing 'easy credit' - may address behavioural concerns about the effects of advertising on consumer choice; and the 'toxic' product model underlines the need to identify those attributes of credit products which are potentially dangerous - a task currently being undertaken by the $\mathrm{FSA}^{49}$. Minimum standards may be justified. Close attention to the actual costs and benefits of regulation should be substituted therefore for a priori approaches based on choice or protection. The institutional approach underlines the contingent nature of credit markets as artefacts of political choices - and the importance of ensuring democratic participation in their regulation. A normative starting point could be that consumer credit should not be regressive, since that may deepen existing inequalities and it should enhance individuals' capabilities, adopting the language of $\operatorname{Sen}^{50}$. These objectives may seem relatively uncontroversial but credit provision has arguably failed to achieve them in the UK where much consumer credit is based on regressive crosssubsidisation, the structure of bank fees and credit card fees in the UK representing two examples.

Expertise and social science may reduce policy disagreement and evidence based policy is an accepted norm in policy making. One characteristic of the new credit regulation is the embedding of research in policy making. For example, the US Consumer Financial Protection Bureau (CFPB) must test consumer disclosures before their introduction. The OECD has recently outlined the importance of strengthening evidence-based impact assessment to support policy coherence, paying more attention to the voice of users (consumers), who need to be part of the regulatory development process and the increased importance of measuring the distributional (equitable) impact of regulation. This could have two consequences in credit regulation; it could require assessing the impact of regulation on financial inclusion and also placing greater weight on the benefits of regulation to more vulnerable groups.

There are limits to expertise. There may be a division of opinion among experts, and in policy making there is always the danger of overstating the findings of studies, particularly if the studies contain quantitative data. Policy making should not necessarily follow the latest fashion in behavioural analysis. There is also the issue of relevant expertise. Following the world financial crisis and the apparent limits of economic expertise in anticipating the crisis one suggestion is that policy making should draw on wider sources from sociology and history, particularly in the case of household credit where individuals may fit uneasily the model of a rational utility maximiser.

\footnotetext{
${ }^{49}$ Financial Services Authority, Product Intervention (cf fn 17).

${ }^{50}$ See Sen, fn 21.
} 
The contested nature of evidence on issues such as payday loans, SMSs, and the role of interest rate ceilings, underlines the importance of the political decision making process on consumer credit and the challenge of ensuring an 'ideal speech' mode for discussion of credit. Issues in consumer credit are sometimes constructed as 'expertise versus populism'. There are dangers in populism. Indeed much of the better regulation literature underlines its importance in counteracting 'knee jerk' responses to problems. The World Bank echoes this critique in its comment: 'The political response to a collapse of a part of the financial system may be to over-compensate with heavy regulation. As a reaction to increasing public pressure to adopt consumer protection measures, some governments have resorted to imposing interest rate caps for consumer loans, thus undermining development of credit markets. ${ }^{51}$. No citation is provided however to support this sweeping statement. It may be true in relation to a specific country, adopting a specific measure, at a specific time. However, many countries with relatively highly developed credit systems, such as France, have interest rate ceilings. Interest rate ceilings have costs and benefits and these depend on the particular nature of the ceilings. The absence of consensus on this issue suggests that there is no 'end of history' on the debates over ceilings ${ }^{52}$. Expertise may secrete biases - 'taken for granted' assumptions - among groups of experts with similar world views. It is therefore important to expose clearly the potentially competing normative assumptions - to ensure 'reasoned scrutiny from different perspectives ${ }^{53}$.

The political economy of internationalization of consumer finance regulation

Discussion of the role of expertise in politics returns us to the political economy of the internationalization of consumer finance norms. 'Neo-liberals are (...) profoundly suspicious of democracy' argues Harvey and tend to 'favour governance by experts and elites ${ }^{54}$. Majone's model of legitimacy through expertise ${ }^{55}$ applied primarily to regulation with clear objectives which can be monitored does not seem adequate for the complexities of consumer credit regulation where distributional issues and fairness may often be important. Joerges' and Neyers' model of 'deliberative suprana-

\footnotetext{
${ }^{51}$ World Bank, Good Practices for Consumer Financial Protection: Consultative Draft 96.

${ }^{52}$ Ramsay, 'To Heap Distress upon Distress'; Comparative Reflections on Interest Rate Ceilings University of Toronto Law Journal (2010) $60,707,708$.

${ }^{53} \mathrm{Sen}$, The Idea of Justice 45.

${ }^{54}$ Harvey, NeoLiberalism: A Brief History (2005) 65.

${ }^{55}$ Majone, Regulatory Legitimacy in Regulating Europe (1996) 284 301.

tionalism'56 where decisions should emerge from 'careful and informed judgment' faces the problem in the area of financial services that the 'deliberations' may be dominated by elite groups without fostering wide participation ${ }^{57}$. The world financial crisis demonstrated that the existing status quo of regional and international financial regulation, often dominated by expert insiders, was inadequate.

There are well-known arguments concerning the difficulties in representing the consumer interest at the national level, given the diffuse and fragmented nature of the consumer interest ${ }^{58}$. These difficulties may be exacerbated at the regional and international level. Financial issues are complex and regulators must inevitably draw on industry expertise but it is often difficult to ensure adequate representation of the heterogeneity of consumer interests. However, although the financial industry can appear very powerful in terms of its lobbying power and ability to buy expertise, regulation without consumer support lacks legitimacy ${ }^{59}$. In addition, the genuine tragedies which are associated with the dark side of consumer credit can stimulate political action. The existence of institutions such as BEUC and CI permit greater pooling of information and expertise.

The "international" is now an important aspect of consumer protection in terms of international standard setting, the growth of regulatory networks, and the influence of 'modeling' - where particular models of regulation are diffused internationally. An example is the internationalization of Warren's product safety model of credit regulation. A characteristic of the internationalization of regulation is the emergence of international networks of enforcers such as the International Organisation of Securities Commissions (IOSCO) and the International Competition network. Within the EU the Commissionhas promoted public enforcementnetworking through itsRegulation on consumerprotection cooperation2006/2004/ EC as well as the growth of comitology which Joerges describes as 'flexible expert governance'. International bodies such as the OECD are sites for linking networks and developing norms and principles of best practice. The establishment of newnational public regulatorsmaystimulateinternationalnetworks 'exchanging information, co-ordinating national policies, and working together to address common problems ${ }^{90}$.

\footnotetext{
${ }^{56}$ Joerges/Neyer, From Intergovernmental bargaining to deliberative political processes: The constitutionalisation of comitology, European Law Journal 1997, 273.

${ }^{57}$ Weiler, 'Comitology' as Revolution-infranationalism, constitutionalism and democracy, in Joerges/Vos (Eds), EU Committees: Social Regulation, Law and Politics (1999) 339, 348.

${ }^{58}$ Ramsay, Consumer Law and Policy: Text and Materials on Regulating Consumer Markets (2007) 18-31.

${ }^{59}$ Trumbull, Consumer Policy in Coen/Grant/Wilson, The Oxford Handbook on Business and Government (2010) ch 26.

${ }^{60}$ Slaughter, Global Government Networks, Global Information Agencies and Disaggregated Democracies, Michigan Journal of International Law 24 (2003) 1041, 1043.
} 
International cooperation on financial consumer protection remains modest, and has focused primarily on financial literacy. CI proposes a new international network structure which would facilitate co-operation between national financial consumer protection regulators. The organization would have a consultative role with international financial regulatory bodies and would include an independent consumer panel to "monitor, advise and challenge the work of the organization" with the ability "to conduct its own research and publish its views and findings" ${ }^{1}$. Such a 'global information agency', could assist in ensuring greater legitimacy and accountability for financial consumer protection.

International networks promise the expansion of global governance without centralization. They can provide a useful site for regulatory learning and the development of an 'epistemic community' of regulators a "loose collection of knowledge based experts who share certain attitudes and values and substantive knowledge, as well as ways of thinking about how to use this knowledge" ${ }^{\text {" }}$. These communities may shape "common sense" about approaches to regulation; they may bring together adversaries. They are also sites for the promotion of strategic interests by national regulators and by powerful states who wish to export their model of regulation and ideas internationally. The US promotes within the OECD an approach to consumer protection "involving flexible market oriented standards backed by aggressive enforcement 'and encourages 'countries to adopt an economics-based approach to consumer protection. ${ }^{63}$. The UK FSA has established an international agenda indicating that it has 'always been a high-profile participant and leader in international and European debates about financial services regulation' ${ }^{64}$. The new French Autorité de Contrôle Prudentiel also intends to promote its approach within international institutions. We do not have much knowledge of the dynamics of these international institutions in the context of consumer finance. The politically charged nature of consumer credit regulation required the OECD, in its development of the Draft Consumer Finance Principles, to consult with a wider range of groups than would normally be consulted. But this could provide a precedent for future development of international soft law on consumer finance. The distributional impact of these international developments,

\footnotetext{
${ }^{61}$ Consumers International, Safe, Fair and Competitive Markets in Financial Services: Recommendations for the G20 on the Enhancement of Consumer Protection in Financial Services (2011) 37 $<$ consumersinternational.org/media/669846/cifinancialreport2011 execsummary.pdf $>$.

${ }^{62}$ Haas, Do Regimes Matter? Epistemic Communities and Mediterranean Pollution Control, International Organization (1998) 43.

${ }^{63}$ FTC Annual Report 2006, 49; in the UK see the FSA, The FSA's International Agenda (2010)

${ }^{64}$ The Financial Services Authority, The Financial Services Authority International Agenda (2010)
}

and their legitimacy and accountability are important questions. International networks have, for example, provided an opportunity for the extensive promotion of financial literacy out of proportion to the scientific evidence in its favour.

The effectiveness of international networks may depend on whether there are common preferences among national participants. Part of the success of IOSCO in relation to transnational securities fraud is the central role of the capital markets in most countries which would be undermined even by fraud which is only targeted at foreigners ${ }^{65}$. Differences exist however in approaches to consumer credit regulation even between high-income countries of the North. These may partly reflect both ideology and the influence of financial industries in the economy. Regional consumer organizations may not agree on what constitutes a 'toxic' product. BEUC in its response to the EU consultation on responsible lending noted certain products as 'toxic' that should be prohibited but which the English Consumer Association Which? thought should merely be regulated. ${ }^{66}$ Emerging countries are involved now in regulation through the G20 in the development of consumer principles and the increased diversity of views may create difficulties in reaching consensus.

\section{Institutional structures: technocracy, politics and the new regulation}

Michael Moran: "We have to fashion a new ideology of public interest regulation, and a new confidence in that regulation: it existed when the American New Deal institutions found their feet; it must be rediscovered." ${ }^{\circ 7}$.

Contemporary consumer credit regulation includes regulation by central banks, a general consumer protection regulator or a specialized regulator. Public interest litigation plays a role in some countries. A minority of countries have a dedicated consumer finance regulator (UK, Canada, Australia); the US Consumer Financial Protection Bureau (CFPB) focuses only on consumer and mortgage credit. The expert regulator with greater ex ante regulatory powers has

\footnotetext{
${ }^{65}$ Verdier, Transnational Regulatory Networks and their Limits, Yale Journal of International Law 2009, 146.

${ }^{66}$ See Responsible Lending and Borrowing in the EU Public Consultation 2009, 10. See also the approach of the UK Consumer Financial Services Panel to regulation 'A healthy market needs to achieve a balance between freedom for those who are able to repay their mortgages and understand the risks and those consumers who are vulnerable and need greater protection', Financial Services Consumer Panel, Six Point Plan for a Healthy and Sustainable Mortgage Market (2011) at 2 $<$ fs-cp.org.uk/publications/pdf/fscp_mmr_plan.pdf $>$.

${ }^{67}<$ irisheconomy.ie/index.php/2010/06/23/regulation-and-thefinancial-crisis/>.
} 
emerged as an influential model. ${ }^{68}$ These developments in consumer finance regulation promise greater opportunities for policy learning between the EU and North America concerning the role of public agencies in regulation.

The traditional rationales for an independent regulatory agency include: expertise, continuity and the ability to respond flexibly to changing market practices. An optimal expert regulatory regime should be well funded, have a range of sanctions, be able to obtain information at a low cost on emerging market practices, assess accurately those practices creating the greatest risks for consumer, and be structured to be responsive to all groups affected by its activities. These simple requirements can provide international benchmarks for comparison. Warren emphasized the supervision power in the new CFPB as enabling early intervention before problems become national issues, the FSA (in whatever is its new guise in conduct of business regulation) in the UK promises "greater willingness to intervene in the early stages of the product lifecycle", with support for the power to intervene to "ban specific products" 69 and the OFT under its licensing powers increasingly scrutinizes the business models of firms in higher risk credit granting.

The objectives of the new UK and US agencies include promoting competition, transparency and choice, protecting consumers from unfair and abusive practices, and facilitating access and innovation. Rulemaking by the CFPB must take into account the effects on financial inclusion for traditionally underserved groups. There is a tension within the mandates between consumer choice and consumer protection, between fostering innovation and choice while protecting against unfairness and abuse. ${ }^{70}$

Successful regulation depends on political support and the authority of the agency. Study of regulation has progressed beyond the simple dichotomy of regulators as guardians of the public interest or regulators as 'captured' by industry. Regulators must often draw on non-governmental actors and operate within regional and international policy networks, and an international environment of benchmarking and comparison against norms of "better regulation" - often requiring quantitative measures of output and transparency in their operation.

Legislation establishing agencies can confer a variety of powers on third party monitors, drawing on Ayres' and

\footnotetext{
${ }^{68}$ See discussion in The BEUC report by IFF, Financial Supervision in the EU: A Consumer Perspective (2011).

${ }^{69}$ Sants, Creating the FCA < fsa.gov.uk/pages/Library/Communication/ Speeches/2011/0302_hs.shtml>.

${ }^{70}$ In the US see Section 1021 lit b para 1-5 Consumer Financial Protection Act 2010 Public Law 111-203 (124 STAT 1980) <gpo.gov/fdsys/ pkg/PLAW-111publ203/pdf/PLAW-111publ203.pdf>. This tension is also evident in UK proposals: see UK Treasury, A New Approach to Financial Regulation: The Blueprint for Reform (Cm 8083) June 2011 para 1.39-1.44.
}

Braithwaite's model of tripartism ${ }^{71}$. These may include the provision of information and 'initiation rights', conferring powers on public interest groups to put items on the regulatory agenda - the UK supercomplaint procedure ${ }^{72}$ being an example - or ensuring effective consumer representation on the agency. In the UK the FSA Financial Services Consumer Panel, financed by the FSA, provides the consumer view, in France the Comité Consultatif du Secteur Financier, brings together different industry, business and consumer groups in a quasi-corporatist model ${ }^{73}$. At the EU level, the establishment by DG Market of the Financial Services Users Group represents an attempt to provide more effective representation of investors and consumers. ${ }^{74}$ The majority of the 20 members represent the interests of consumers and retail investors and the Group will have a modest research budget.

Private enforcement might also play a role. This can address public budgetary constraints, be more responsive to consumer preferences, have information advantages in detecting problems, and represent potentially iconoclastic and innovative strategies. The converse is that private enforcement permits governments to achieve regulation off- budget, and may lead to disorganized and uneven enforcement and doctrine. An alternative in consumer financial services is a Financial Ombudsman which, in addition to providing low cost redress for consumers can signal to regulators emerging issues which demand a more systematic response. The Financial Services and Markets Act in the UK also permits a regulator to require firms to establish a consumer redress scheme where systematic problems have arisen. ${ }^{75}$

The limits of the expert agency are the ability to hire and retain individuals with expertise, and to keep ahead of changing practices. There may be difficulties in monitoring markets with large numbers of small firms. Middle income or developing countries may face difficulties in adequately staffing an agency. General consumer protection agencies often do not have the knowledge or resources to credibly address consumer financial services.

Much consumer financial regulation is implemented through detailed regulations or guidance. Legislation may often provide only a framework so that success for political

\footnotetext{
${ }^{71}$ Ayres/Braithwaite, Responsive Regulation: Transcending the Deregulation Debate (1992) ch 3, 57 et seq (fn 32).

${ }^{72}$ See 11 Enterprise Act 2002.

${ }^{73}$ See discussion of different models in the French CCSF report 2008-09 chapter $9<$ ebookbrowse.com/ccsf-2008-09-ichapitre-9-pdfd41535038>.

${ }^{74}$ See Commission Decision 2010/C 199/02 of 20.07.2010 setting up a Financial Services User Group.

${ }^{75}$ See s14 Financial Services Act 2010 inserting s404 Financial Services and Markets Act 2000 permitting the agency to require firms to establish consumer redress schemes where there has been 'widespread or regular failure by relevant firms to comply'.
} 
groups depends on their ability to influence this phase of regulation. Consumerists fear that symbolic legislative victories may be undercut in the detailed low visibility of the regulation process. In addition the nature of rulemaking in a country such as the US provides substantial opportunities for techniques associated with adversarial legalism - such as technical objections to the development of a rule ${ }^{76}$.

The success of regulation cannot be measured solely by the number of prosecutions or litigation. Outcomes rather than outputs matter. Reductions in complaints may be an ambiguous measure of success since more complaints may be stimulated by high profile enforcement. It is difficult to establish quantitative measures of the effects of enforcement on consumer market detriment. These factors make international comparison of the effectiveness of consumer credit regulation difficult. Jackson has shown the difficulties of quantitative comparisons of enforcement of securities law between the US and the $\mathrm{UK}^{77}$. However, increased internationalization demands that scholars should attempt comparative empirical studies of enforcement.

Shaping the international ground rules of credit: Ex ante control through responsible lending and fairness norms

Regulation may establish a new set of market ground rules. The concept of 'responsible lending' represents the international embodiment of new ground rules. It now has many iterations throughout the world ${ }^{78}$, but its thrust is that lenders should assess whether individuals are likely to be able to repay (and not merely determine whether lenders will recover their money e.g. through a sale of the debtor's assets), and ensure that a credit product should not be unsuitable for the consumer. Responsible lending envisages a change in the nature of a credit contract so that the lender must take into account the other party's interests and needs throughout the relationship, and not act solely in her own interest. It is not a fiduciary relationship but represents a stronger relationship of solidarity. Indeed if one adds up the international acquis of consumer credit protection rules, guidance, and soft law etc then a distinct image of economic and social

\footnotetext{
${ }^{76}$ See generally Kagan, Adversarial Legalism: The American Way of Law (2001).

${ }^{77}$ Jackson, The Impact of Enforcement: A Reflection, University of Pennsylvania Law Review 2009, 400, 402-406.

${ }^{78}$ See e.g. Art 5, 14: Proposal for a Directive COM (2011) 142 final on credit agreements relating to residential property; Art 8, Art 5 para 6 Consumer Credit Directive; UK Section 55A Consumer Credit Act 1974 implementing the EU Consumer Credit Directive; Section 129 Australian National Consumer Credit Act and Australian Securities and Investment Commission (ASIC) Regulatory Guide 209 Responsible Conduct; Office of Fair Trading, Irresponsible Lending OFT Guidance for Creditors OFT 1107 (August 2010) para 4; South Africa National Credit Act 2005 Section 80.
}

relationships appears, which differs from classical contract law $^{79}$.

There is also the effect of responsible lending norms on corporate culture. This is after all the aim of responsible lending - to embed trust in the marketplace and ensure that credit does meet consumer needs. The OECD draft principles state that "treating consumers fairly should be an integral part of the day to day good governance and corporate culture of financial service providers ${ }^{90}$. If financial firms are primarily amoral calculators, then they may seek methods to reduce the effects of this obligation, perhaps through the installation of bureaucratic procedures which provide perfunctory compliance.

The FSA in the UK has attempted to change the culture of financial firms through its "treating customers fairly" initiative $^{81}$ a broader but analogous principle to responsible lending. The FSA initiative on treating customers fairly provided an intriguing experiment by requiring companies to ensure that fair practices were embedded in their organizational culture and throughout the product lifecycle with products designed to meet consumer needs. The FSA monitored firms' progress towards achieving these goals and took enforcement action where it failed to meet these goals. One of the consequences of this initiative was the revelation of the extent to which many national and international firms had structures of incentives and procedures for monitoring which created substantial risks of misselling.

The experiment indicated however the difficulties in changing organizational behavior ${ }^{82}$. Firms initially reacted to the initiative with some confusion and resistance because they thought that they did treat their customers fairly and there was a dissonance between this view and public views on misselling. The FSA initiative opened the corporate black box of decision making but illustrated the extent to which organisations resist external changes. Moreover there was no guarantee that the multinational firms involved in several of the prosecutions in the UK initiative, would not use similar techniques in other countries. It is here that the CI "information agency" could play a role in highlighting the practices of multinational financial firms.

\footnotetext{
${ }^{79}$ Ramsay, Regulation of Consumer Credit, in Howells/Ramsay/Wilhelmsson, Handbook of Research on International Consumer Law (2010) 371-372.

${ }^{80}$ OECD, Draft High Level Principles on Financial Consumer Protection (2011) 5 <oecd.org/dataoecd/31/9/48473101.pdf>.

${ }^{81}$ For discussion of this initiative see Williams, Open the Box: An exploration of the FSA's model of fairness in consumer transactions, in Devenney/Kenny/Fox-Mahoney, Unconscionability in European Private Financial Transactions (2010) ch 12, 227-245.

${ }^{82} \mathrm{Gilad}$, Institutionalizing Fairness in Financial Markets: Mission Impossible? Regulation and Governance (2011) 309-332.
} 


\section{Over-indebtedness, default and the ground rules of bankruptcy}

The development of international norms of consumer insolvency has not been part of the work of international development agencies or institutions such as UNCITRAL. In contrast, corporate bankruptcy has been viewed as a key to assuring credit market development and the management of risk. At a regional level, the EU has promoted more efficient debt collection procedures and advocated more generous treatment of failing entrepreneurs by reducing bankruptcy stigma $^{83}$. The treatment of multiple consumer over-indebtedness, has primarily been approached through 'soft' measures such as the development of best practices and the promotion of research ${ }^{84}$.

The reluctance to discuss individual bankruptcy as an integral part of credit reform may represent several ideas ${ }^{85}$ : that an effective bankruptcy system does not facilitate the development of the consumer credit market and may have a deleterious effect on payment culture; that it is more important to unleash credit and deal subsequently with the inevitable costs; or the bounded rationality (political calculation?) of politicians who prefer to discuss the immediate benefits of credit rather than its longer term downside. The idea that promises should be kept - pacta sunt servanda - is a strong ethical principle and there is unlikely to be much political support for anything which smacks of the "right not to pay one's debts'. Policy making on consumer debt tends to be $e x$ post, in response to a perceived crisis of debt.

The structure of consumer bankruptcy rules is important to credit markets. They may affect credit granting and availability; they are increasingly an aspect of social and family policy, for example in relation to the protection of the family home and policies against social exclusion; they determine how to share the pain of the many financial crises which have occurred during the past decades, and which may recur; a "loans for wages" model of the economy is more likely to create the risk of default. Bankruptcy reveals the tension between neo-liberalism and the social market in models of contract, for example the extent to which a new vision of social force majeure is recognized in contrast to pacta sunt servanda. From a prudential viewpoint it may be desirable to institute a dignified exit and re-entry procedure for the over-indebted individual. Systematic debt default can be "political dynamite" as evidenced by the Microfinance

\footnotetext{
${ }^{83}$ See European Commission, Overcoming the stigma of business failure - for a second chance policy Implementing the Lisbon Partnership for Growth and Jobs, COM (2007) 584 final 3.

${ }^{84}$ European Commission DG EMPL, Towards A Common Operational European Definition of Over-Indebtedness (2008) <bristol.ac.uk/ geography/research/pfrc/themes/credit-debt/pfrc0805.pdf>.

${ }^{85}$ Feibelman, Consumer Bankruptcy as Development Policy, Seton Hall Law Review 2009, 63.
}

scandal in India. Bankruptcy mechanisms may be particularly important for countries which do not have extensive social safety nets.

In the wake of the world financial crisis the World Bank has now established a working group on individual insolvency recognizing the problem of consumer insolvency as a systemic risk to the financial system ${ }^{86}$. Preliminary research indicates that although only $16 \%$ of high-income economies do not have a collective procedure for consumer insolvency, more than $50 \%$ of low and middle income economies do not have collective individual insolvency systems. Significant differences remain between countries with individual insolvency systems, and the process of developing this area implicates many interests beyond creditors or debtors, such as Ministries of Justice and Trade, Social Security and professional insolvency practitioners or counselors. It is a politically charged area because there is little political capital for politicians permitting consumers not to repay their debts. Consumers as borrowers may not have sympathy with consumers as debtors. Success in the treatment of overindebtedness may depend on a good infrastructure of courts, judges or other experts which is often a costly undertaking which cannot be financed by debtors who rarely have substantial funds to pay for assistance or advice.

\section{Conclusion}

Consumer finance regulation draws on multiple disciplines and methodologies ${ }^{87}$. Its increased prominence in the wake of the world financial crisis challenges scholars to map the new architecture of consumer finance regulation and to understand the linkages between the national, regional and international. Interdisciplinary analysis, drawing on tools such as interest group analysis, principal-agent and game theory may provide useful frameworks. The regulatory challenges are those of blending expertise with political responsiveness to the range of distinct perspectives on the role of consumer credit. Information for monitoring and as a basis for informed debate is a key resource for ensuring legitimacy and accountability and the CI proposal for an international Information Agency is a useful start. Transparency is 'an emergent property of globalization' ${ }^{88}$, which should not be underestimated.

\footnotetext{
${ }^{86}$ World Bank, Best Practices in the Insolvency of Natural Persons, Rapporteur's Synthesis <siteresources.worldbank.org/EXTGILD/ Resources/WB_TF_2011_Consumer_Insolvency.pdf $>$.

${ }^{87}$ Tufano, Consumer Finance, Annual Review of Financial Economics, 2009, 227, 241; Campbell/Jackson/Tufano, Consumer Financial Protection, Journal of Economic Perspectives 2011, 91, 109.

${ }^{88}$ Braithwaite/Drahos, Global Business Regulation (2000) 606.
} 